\title{
Controlled Ski-jump Spillway Model Design According to IS code
}

\author{
V. S. Chavhan, G. A. Hinge
}

\begin{abstract}
Ogee spillways are used to monitor reservoir releases. Ogee spillway is a weir with an ogee (S-shaped) overflow profile. A curve solid surface provided at the toe of the spillway is known as a ski-jump bucket. Ski-jump bucket type energy dissipator is considered more suitable when tail water depth is much lower than the sequent depth of a hydraulic jump. In the ski-jump bucket, the flow coming down the spillway is thrown away in air from the toe to a considerable distance as a free discharging upturned jet (trajectory), which falls on the channel bed downstream. In the ski-jump bucket, only part of the energy is dissipated through interaction of the jet with the surrounding air. The remaining energy is accorded to the channel bed below. This paper describes the design of a Controlled ski -jump spillway model with guidelines in accordance with the IS Code.
\end{abstract}

Keywords: Ogee spillway, Ski-jump bucket, Radial gate, Physical model, Trajectory, IS code.

\section{INTRODUCTION}

A spillway is a channel or route through which flood / surplus water escapes or drains safely from a reservoir or dam. They are provided for all dams as a safeguard against overtaking and the resulting damage and failure. This serves as a safety value for the dam. The spillway must be hydrodynamic and structurally safe. An Ogee shaped (or overflow) spillway is the most commonly used spillway. It is widely used with gravity dams, arch dams and buttress dams. Many earth and rock fill dams have also been provided with such spillways as superstructures. An Oge-shaped spillway has an Ogee shaped control weir, similar to the long English letter "S". The upper part of the surface of the spillway closely resembles the profile of the lower nappe of a ventilated sheet of water, which falls independently of a high-velocity weir. A spillway with control mechanism is almost always provided for release

Water during additional floods. Can also be done by water residues Control devices provided in the groove in the body of the dam and tunnels. For Flow control, a gate or shutter is provided which consists of a leaf or a close member, to control the flow of water, it is placed across the waterway from outside position.

\section{Revised Manuscript Received on February 05, 2020.}

* Correspondence Author

V S Chavhan*, Assistant professor in the Department of Civil Engineering, AISSMS College of Engineering, Savitribai Phule Pune University, Pune, Maharashtra, India.

Dr. G A Hinge, Professor and Principal, BSCOE and research, Narhe, Savitribai Phule Pune University, Pune, Maharashtra, India.

(C) The Authors. Published by Blue Eyes Intelligence Engineering and Sciences Publication (BEIESP). This is an open access article under the CC BY-NC-ND license (http://creativecommons.org/licenses/by-nc-nd/4.0/)
Flow control in closed pipes such as penstocks that send water for hydropower Also done by valves, which are separated from the gates in the sense that they come together With driving equipment, while gates require a separate drive or hoisting equipment. Radial gate are hinged gates, in the form of a circular arc with the centre of curvature at the trunnion.

Ski-jump bucket energy dissipator become popular for large dams in recent years due to its ability to safely convey high velocity flow in excess of $20 \mathrm{~m} / \mathrm{s}$ to the downstream plunge pool. In a Ski-jump bucket energy dissipator flow is

discharge in the form of trajectory away from the hydraulic structure into a plunge pool. Trajectory bucket, flip bucket, free jet spillways and free over-falls are the different names of Ski-jump bucket energy dissipator in different country. Ski-jump bucket energy dissipater structures consist of three main sections: 1 .Ski-jump bucket, 2.Ski-jump/Trajectory and 3. Plunge pool.

\section{PROROTYPE SPILLWAY DESIGN DATA AND MODEL SCALE}

The general prototype spillway data used for design is given in table I.

Table- I: Prototype spillway Design data
\begin{tabular}{|c|l|}
\hline Design discharge $\left(\mathrm{Q}_{\mathrm{P}}\right):$ & $\begin{array}{l}946.90 \\
\mathrm{~m}^{3} / \mathrm{s}\end{array}$ \\
\hline Length of spillway $\left(\mathrm{L}_{\mathrm{P}}\right):$ & $30 \mathrm{~m}$ \\
\hline Height of spillway $\left(\mathrm{H}_{\mathrm{P}}\right):$ & $21.2 \mathrm{~m}$ \\
\hline
\end{tabular}

The model was designed with a scale of 1:100, which was the largest possible scale. The scale was determined (ref. Equation 1) as per prototype spillway design data and as per details of hydraulic flume (table II).

Table- II: Details of hydraulic flume

\begin{tabular}{|l|l|}
\hline Maximum discharge capacity $\left(\mathrm{Q}_{\mathrm{F}}\right):$ & $0.010 \mathrm{~m}^{3} / \mathrm{s}$ \\
\hline Width of flume $\left(\mathrm{W}_{\mathrm{F}}\right):$ & $0.30 \mathrm{~m}$ \\
\hline Height of flume $\left(\mathrm{H}_{\mathrm{F}}\right):$ & $0.30 \mathrm{~m}$ \\
\hline Length of fume $\left(\mathrm{L}_{\mathrm{F}}\right)$ & $6 \mathrm{~m}$ \\
\hline$\frac{Q_{P}}{Q_{M}}=L_{Y}{ }^{2.5}$ &
\end{tabular}

The Froude number and similarity between prototype and model were assumed to be equivalent i.e.:

$F r_{\text {prototype }}=F r_{\text {model }}$

The scale relationship obtained is shown in table III, is valid for the model and prototype (model representation is denoted by suffix ' $m$ ' and prototype by suffix ' $p$ ').

Table- III: Scale relationship

\begin{tabular}{|l|l|}
\hline Froude number ratio: & $F r_{p} / F r_{m}=1$ \\
\hline Linear ratio: & $L_{\mathrm{p}} / L_{m}=\mathrm{L}_{\mathrm{r}}=100$ \\
\hline Area ratio: & $L_{\mathrm{p}}{ }^{2} / L_{m}{ }^{2}=\mathrm{Lr}_{\mathrm{r}}{ }^{2}=10000$ \\
\hline Volume ratio: & $L_{\mathrm{p}}{ }^{3} / L_{m}{ }^{3}=\mathrm{L}_{\mathrm{r}}{ }^{3}=1000000$ \\
\hline
\end{tabular}




\begin{tabular}{|l|l|}
\hline Velocity ratio: & $V_{p} V_{m}=\mathrm{L}_{\mathrm{r}}{ }^{0.5}=10$ \\
\hline Discharge ratio: & $V_{p} V_{m} \times L_{\mathrm{p}}^{2} L_{m}^{2}=\mathrm{Lr}_{\mathrm{r}}^{2.5}=$ \\
& 100000 \\
\hline
\end{tabular}

From the prototype spillway design data and selected scale different parameters for spillway model were calculated are shown in table IV.

Table IV: Parameters for spillway model

\begin{tabular}{|l|l|}
\hline Design discharge $\left(\mathrm{Q}_{\mathrm{M}}\right):$ & $0.0946 \mathrm{~m}^{3} / \mathrm{s}$ \\
\hline Length of spillway $\left(\mathrm{L}_{\mathrm{M}}\right):$ & $0.30 \mathrm{~m}$ \\
\hline Height of spillway $\left(\mathrm{H}_{\mathrm{M}}\right):$ & 0.212 \\
\hline
\end{tabular}

\section{DESIGN PARAMETERS FOR OGEE SPILLWAY MODEL}

The ogee spillway is one of the most studied hydraulic structures. Ogee Spillway has its overflow profile conforming to the profile of the lower nappe of water issuing over a sharp crested weir. IS 6934 (1998) recommends hydraulic design of ogee spillway [1]. Design of Ogee spillway consists of determining:
A. Design Head and
B. Ogee Profile $(\mathrm{d} / \mathrm{s}$ and $\mathrm{u} / \mathrm{s})$

\section{A. Design head}

The discharge passing over the ogee spillway model is given by the equation:

$Q_{M}=C_{x} L_{e} H_{e}^{3 / d_{2}}$

Where $\mathrm{Q}_{\mathrm{M}}=$ Design Discharge

$\mathrm{L}_{\mathrm{e}}=$ Effective length of the spillway crest

$\mathrm{C}=$ Coefficient of discharge

$\mathrm{H}_{\mathrm{e}}=$ Effective head over the spillway

Since the given spillway is a high spillway, coefficient of discharge may be assumed to be 2.2 and assuming, $\mathrm{L}_{\mathrm{e}}=\mathrm{L}_{\mathrm{M}}$. After putting value of $\mathrm{Q}_{\mathrm{M}}, \mathrm{C}$ and $\mathrm{L}_{\mathrm{e}}$ in equation (3) we get: $H_{e}=0.059 \mathrm{~m}$.

\section{B. Ogee profile (d/s and $u / s)$}

The $d / s$ profile for a u/s vertical face is given by the equation: $x^{1.85}=2 . H_{e}^{0.85} \cdot y$

$$
\text { or } y=x^{1.85} / 0.180
$$

Differentiating equation (4) w.r.to x we get:

$\frac{d y}{d x}=\frac{1.85 x^{0.185}}{0.180}$

The $\mathrm{d} / \mathrm{s}$ slope (i.e. $\frac{d y}{d x}$ ) of the spillway is assume to be $1 \mathrm{~V}: 0.7$

H. From equation (6) we get: $x=0.0981 \mathrm{~m}$.

The $\mathrm{y}$ co-ordinates for $\mathrm{d} / \mathrm{s}$ profile from $\mathrm{x}=0$ to $\mathrm{x}=0.0981 \mathrm{~m}$ are given in table $\mathrm{V}$.

Table- V: Co-ordinates for $\mathrm{d} / \mathrm{s}$ profile

\begin{tabular}{|c|c|}
\hline $\mathrm{x}$ in $\mathrm{m}$ & $y=x^{1.85} / 0.180$ in $\mathrm{m}$ \\
\hline 0.01 & 0.0011 \\
\hline 0.02 & 0.0039 \\
\hline 0.04 & 0.014 \\
\hline 0.06 & 0.030 \\
\hline 0.08 & 0.052 \\
\hline 0.0981 & 0.075 \\
\hline
\end{tabular}

The $\mathrm{x}$ and $\mathrm{y}$ co-ordinates for $\mathrm{u} / \mathrm{s}$ profile were calculated by using equation (7) and (8) and are shown in table VI.

$$
\begin{aligned}
& y=\frac{0.724\left(x+0.27 H_{e}\right]^{1.80}}{H_{e}} 0.126 H_{e}-0.4315 H_{e}{ }_{e}^{0.375}(x+ \\
& \left.027 H_{e}\right)^{0.625} \\
& x=-0.27 H_{e}
\end{aligned}
$$

Table VI: Co-ordinates for $\mathrm{u} / \mathrm{s}$ profile

\begin{tabular}{|c|c|}
\hline $\mathrm{x}$ in $\mathrm{m}$ & $y$ in $\mathrm{m}$ \\
\hline-0.005 & 0.0045 \\
\hline-0.01 & 0.0198 \\
\hline-0.015 & 0.0555 \\
\hline-0.02 & 0.0743 \\
\hline
\end{tabular}

\section{DESIGN PARAMETERS FOR SKI-JUMP BUCKET}

A curve solid surface provided at the toe of the spillway is known as a ski-jump bucket. As per IS 7365 (2010), hydraulic design of ski-jump bucket consists of determining [2]:
A. Shape of the bucket
B. Invert elevation of the bucket
C. Radius of the bucket
D. Lip angle of the bucket
E. Ski-jump (trajectory) length and
F. Ski-jump (trajectory) height

\section{a. Shape of the bucket}

Generally a circular shape is preferred from practical consideration. A triangular bucket is an attractive alternative to the standard circular-shaped ski jump bucket. Although few researchers have been studied performance of triangular shape bucket, design guidelines so far not been systematically addressed. Hence, a circular bucket has been preferred in this study.

\section{b. Invert elevation of the bucket}

Invert elevation of the bucket depends on the tail water level. With the considerations of economy and beneficial ground roller action below the end sill, an attempt should be made to fix the bucket invert as close to the ground as possible. In such cases the bucket invert is decided so as to provide a minimum concrete cover of $1.5 \mathrm{~m}$ over the river bed.

\section{c. Radius of the bucket}

The radius of the bucket can be taken to be equal to 0.6 to 0.8 times the geometric mean of the depth of flow over the spillway $(\mathrm{H})$ and the total fall between upstream reservoir pool elevation and the jet surface on the bucket $\left(\mathrm{H}_{5}\right)$ i.e.:

$R=0.6$ to $0.8 \sqrt{\mathrm{HH}_{5}}$

The higher value of 0.8 should preferably be used for model study. From equation (9) we get:

$R=0.8 \sqrt{0.059 .0 .24}$

$R=0.0952 \mathrm{~m}$

\section{d. Lip angle}

Normally adopted lip angle is between $30^{\circ}$ and $40^{\circ}$.

The greater the lip angle greater will be the distance of trajectory throws. A $35^{\circ}$ lip angle has been preferred in this study. 


\section{e. Ski-jump (trajectory) length}

The below equation may be used for calculating the Ski-jump (trajectory) length:

$\frac{X}{H_{V}}=\operatorname{Sin} 2 \Phi+2 \operatorname{Cos} \Phi \sqrt{\operatorname{Sin}^{2} \Phi+{ }^{y} / H_{V}}$

Where $\mathrm{X}=$ Trajectory length

$\mathrm{H}_{\mathrm{V}}=$ Velocity head at bucket lip

$\Phi=$ Lip angle

$\mathrm{y}=$ Height between lip and tail water level

Ski-jump type of energy dissipator is provided when takeoff velocity (In prototype) exceeds $20 \mathrm{~m} / \mathrm{s}$. Assuming prototype velocity as $20 \mathrm{~m} / \mathrm{s}$ and using equation (10) we get:

$X=0.039 \mathrm{~m}$

\section{f. Ski-jump (trajectory) height}

Ski-jump (trajectory) height above the lip may be calculated from the equation below:

$a=\frac{V^{2} \operatorname{Sin}^{2} \Phi}{2 \cdot g}$

Where $\mathrm{a}=$ Trajectory height

$\mathrm{V}=$ Velocity at bucket lip

$\Phi=$ Lip angle

Assuming prototype velocity as $20 \mathrm{~m} / \mathrm{s}$ and using equation (11) we get: $\mathrm{a}=0.0067 \mathrm{~m}$.

\section{DESIGN PARAMETERS FOR RADIAL GATES}

IS 4623 (2000) recommends the design of the radial gate [3]. The design of the radial gates involves determining the location of sill and trunnion and determining the radius of the gate. The sill of the gate shall preferably be located slightly downstream of the crest. The trunnions of the gate shall be so located that under conditions of maximum discharge over the spillway, these should remain at least $1.5 \mathrm{~m}$ clear of the water profile and should in no case be allowed to submerge in the flowing water. The radius of the gate, that is, the distance from the centers of the trunnion pins to the inside face of the skin plate shall, as far as possible, vary from $\mathrm{H}$ to $1.25 \mathrm{H}$ consistent with the requirements of the trunnion location, where $\mathrm{H}$ is the vertical distance between the top of the gate and the horizontal line through the sill. The calculated radius of the gate was $0.0913 \mathrm{~m}$. For this study sill and trunnion of the gate was located at a distance of $0.02 \mathrm{~m}$ and $0.104 \mathrm{~m}$ respectively from the crest of the spillway..

\section{RESULT AND DISCUSSIONS}

After completion of design a 2-D model of the spillway was created in AutoCAD. After 2-D modeling is done, a 3-D model was created is shown in Fig.1

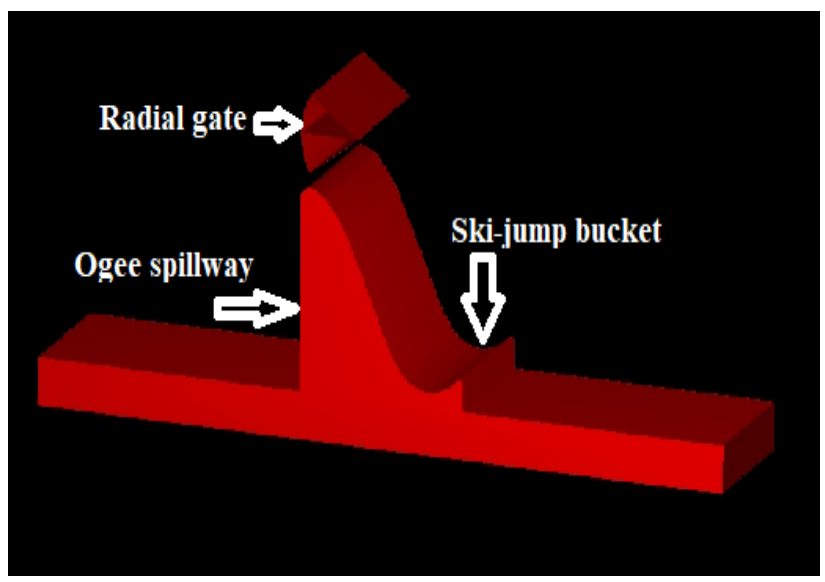

Fig. 1: 3-D Model in AutoCAD

A geometrically 1: 100 scale Froudian 3-D comprehensive spillway model was used to Study of performance of ski jump bucket. The experiments were conducted by placing model in hydraulic flume and it was observed that well trajectory was fomed.

\section{CONCLUSIONS}

Ski jump spillways are a popular type of energy dissipators provided even for sluice spillways of Himalayan dams. The BIS has developed equations for computing trajectory length and height based on the theory of path of the projectile. From the design values the model was fabricated. As per the visual observation, it was found that, clear Ski- jumps were formed for various ranges of discharges in a laboratory flume.

\section{NOTATIONS}

The following symbols are used in this paper:

$\mathrm{Q}_{\mathrm{p}}=$ Prototype design discharge

$\mathrm{LP}_{\mathrm{P}}=$ Prototype spillway length

$\mathrm{HP}_{\mathrm{P}}=$ Prototype spillway height

$\mathrm{Q}_{\mathrm{F}}=$ Maximum discharge capacity of flume

$\mathrm{LF}_{\mathrm{F}}=$ Length of flume

$\mathrm{H}_{\mathrm{F}}=$ Height of flume

$\mathrm{W}_{\mathrm{F}}=$ Width of flume

$\mathrm{Lr}=$ Scale ratio

$F r_{p}=$ Froude number in prototype

$F r_{\text {m }}=$ Froude number in model

$L_{\mathrm{p}}=$ Length in prototype

$L_{\mathrm{m}}=$ Length in model

$\mathrm{V}_{\mathrm{p}}=$ Velocity in prototype

$\mathrm{V}_{\mathrm{m}}=$ Velocity in model

$\mathrm{Q}_{\mathrm{M}}=$ Model design discharge

$\mathrm{L}_{\mathrm{M}}=$ Model spillway length

$\mathrm{H}_{\mathrm{M}}=$ Model spillway height

$\mathrm{L}_{\mathrm{e}}=$ Effective length of the spillway crest

$\mathrm{C}=$ Coefficient of discharge

$\mathrm{H}_{\mathrm{e}}=$ Effective head over the spillway

$\mathrm{x}=\mathrm{x}$ coordinate

$\mathrm{y}=\mathrm{y}$ coordinate

$\mathrm{R}=$ Radius of bucket

$\mathrm{H}=$ depth of flow over the spillway

$\mathrm{H}_{5}=$ total fall between upstream reservoir pool elevation and the jet surface on the bucket

$\mathrm{X}=$ Trajectory length

$\mathrm{H}_{\mathrm{V}}=$ Velocity head at bucket lip

$\Phi=$ Lip angle

$\mathrm{y}=$ Height between lip and tail water level

$\mathrm{a}=$ Trajectory height

$\mathrm{V}=$ Velocity at bucket lip

IS = Indian standard

2-D = Two dimensional

3-D $=$ Three dimensional 


\section{Subscripts}

$\mathrm{p}=$ Prototype

$\mathrm{m}=$ Model

$\mathrm{F}=$ Flume

$\mathrm{e}=$ Effective

$\mathrm{p}=$ Plunge pool

\section{REFERENCES}

1. Bureau of Indian standards., Recommendations for hydraulic design of high ogee overflow spillways, IS: 6934: 1998.

2. Bureau of Indian standards., Criteria for hydraulic design of bucket type of energy dissipators, IS: 7365: 2010.

3. Bureau of Indian standards., Recommendations for structural design of radial gates, IS: 4623: 2000.

\section{AUTHORS PROFILE}

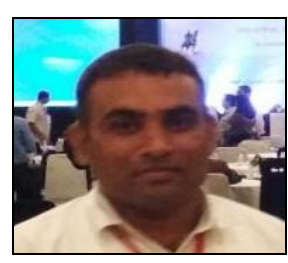

V S Chavhan is a Assistant professor in the Department of Civil Engineering, AISSMS College of Engineering, Savitribai Phule Pune University, Pune, Maharashtra, India. $\mathrm{He}$ is also a Research scholar at BSCOE and Research, Narhe, Pune. He has 14 years of teaching experience.

*Author for correspondance

(vschavhan@aissmscoe.com)

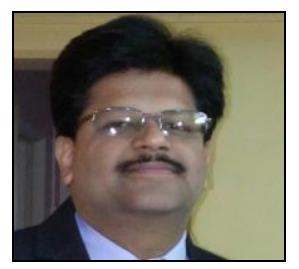

Dr. G A Hinge is a Professor and Principal in the BSCOE and research, Narhe, Savitribai Phule Pune University, Pune, Maharashtra, India. He is also a Research guide. He has 20 years of teaching experience. He has presented research paper in various international and national level conferences and also published research paper in various reputed journals. $\mathrm{He}$ has also filed various patents. At present, he is guiding four numbers of students for Ph. D work. 